\title{
RESEARCH
}

\section{Materialism: A Caring Obituary}

\author{
Riccardo Baldissone
}

\begin{abstract}
The notion of materialism initially appears in the writings of its Christian opponents in late seventeenthcentury England. Only in eighteenth-century France is materialism first posthumously claimed by a Catholic priest, Meslier, and then by authors such as La Mettrie and d'Holbach, at the risk of persecution and imprisonment: Diderot enjoys the hospitality of the fortress of Vincennes for rearranging the materialist stance within his sensualist multiverse. In the nineteenth century, Marx reshapes materialism as part of his critique of decontextualised knowledge. Stirner's discontent with naturalistic objectivity anticipates Nietzsche's rejection of matter in favour of practices: Engels' historical materialism and his ahistorical dichotomic construction of materialism versus idealism are instead embraced by Lenin via Plekhanov, and they are further simplified by Stalin. Nietzsche's approach is recovered by Foucault, Deleuze and Derrida, who challenge both political and theoretical representation. More recently, Barad recasts this challenge into a processual vocabulary, which renews the semantic constellation of realism, materialism and materiality. Whilst not dismissing Barad's new tools, the essay suggests raising the wager: it proposes to extend its own genealogical practice, which reconnects materialism (and matter) with its historical process of production, to any other theoretical object. This recomposition may not only disentangle us from the lexicon of entities - including materialism and matter - but it may also help us to construct a novel and potentially hegemonic language of practices.
\end{abstract}

Keywords: Barad; genealogy; materialism; matter; Meslier; practices

\section{Introduction}

In dealing with the notion of materialism, one is reminded of Friedrich Nietzsche's warning: 'only that which has no history can be defined'1 (2006: 53). Hence, any definition of materialism would entail a denial of the history of materialism itself. More precisely, a definition of materialism would deny two histories: the history of the doctrines that claimed the explicit definition of materialism and the history of the doctrines to which this definition was ascribed. Because the word 'materialism' was invented in seventeenth-century Europe, the second history is both considerably longer and wider than the first one: for example, we use to speak of ancient Greek or ancient Indian materialism (see, e.g., Chattopadhyaya 1959). The historian Le Goff (1984: 362) defended his choice to set the invention of Purgatory in the twelfth century, 'when the noun purgatorium was added to the vocabulary', as a deliberate nominalist approach. In line with Le Goff's nominalist choice, the essay will deal with the uses of the explicit notion of materialism; hence, although it will engage with antiquities in regard to the notion of matter, its genealogical ${ }^{2}$ construction of materialism will only step back through modern times.

University of Westminster, UK

riccardobaldissone@yahoo.com.au
On the one hand, by eschewing retrospective projections of the modern notion(s) of materialism, the essay will be spared the almost impossible task of adapting the texts of non-European and European ancient and medieval authors to modern concerns. On the other hand, by considering only explicit mentions of materialism, it will bypass the difficulties of unambiguously positioning modern thinkers such as Thomas Hobbes and Baruch Spinoza within the materialist camp. The essay will thus follow the uses of the word 'materialism' from its emergence in English late seventeenth-century texts to contemporary times: by doing so, it will provide a rough mapping of the historical trajectory of the corresponding notion of materialism on a textual basis. Such a charting avoids the reduction of the notion of materialism to a mere philosophical concept: on the contrary, by historically contextualising the debates on materialism, the essay will restore materialism's role of theoretical and political tool.

The essay reminds us that materialism does not emerge from academic debate, but as a hypothetical attribution in the texts of its seventeenth-century English opponents; in the eighteenth century, the claims of materialism then gain French writers' persecution and imprisonment. In the nineteenth century, whilst German authors recast materialism, its path no longer immediately coincides with that of radical thinking, as Max Stirner and Karl Marx diverge on the notion of objectivity: their respective 
legacies, which are recovered implicitly by Nietzsche and explicitly by Russian revolutionary leaders, only intertwines again in 1960s France. French theorists such as Michel Foucault, Gilles Deleuze and Jacques Derrida put to work the Nietzschean shift from entities to practices: later on, despite the neoliberal backlash, which restates early-modern individualist anthropology and naturalises markets as the objective Market, Bruno Latour challenges both modern notions of political and scientific representation with his Parliament of Things. In turn, Karen Barad relies on Niels Bohr's construction of quantum physics to reject the representational construction of matter and to claim instead practices of 'spacetimemattering'. The essay suggests taking further these challenges by extending to any other theoretical object its own approach, which reconnects materialism and matter with their historical processes of production. This reconnection does not aim at just recasting matter as a process, but rather at constructing a novel and potentially hegemonic language of practices.

\section{Materialism: A Retrospective The emergence of materialism in the texts of its opponents}

Materialism did not begin its philosophical career as a notion, it appeared in the shape of a nominalised adjective. In 1668, Henry More resorted to the word 'Materialist' in his Divine Dialogues - a book on religion and philosophy - in order to define one of the characters, namely, Hylobares:' ${ }^{3}$ A young, witty, and well-moralized Materialist' (I. sig. B4v). A few years later, in 1674, Robert Boyle deployed the new term with a certain hesitation: 'Chymists and other Materialists (if I may so call them) (...) leave most of the Phaenomena of the Universe unexplicated' (1674: 23). We may notice that Boyle still used the term 'materialist' as an attribution rather than a claim. It was the clergyman Ralph Cudworth who in 1678 put in writing the word 'Materialism', whose notion he traced to remote antiquity: 'Plato and others concluded this Materialism or Hylopathian Atheism, to have been at least as old as Homer, who made the Ocean (or fluid Matter) the Father of all the Gods' (1678: 102). We may notice that Cudworth used the term 'Materialism' as a synonym for 'Hylopathian Atheism', from More's Greek

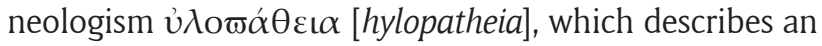
'affection of a Spirit (...) so firmly and closely united to a body, as both to actuate and to be acted upon, to affect and be affected thereby' (1655: 311-312).

In 1702, the materialist attribution was repeated by Gottfried Leibniz (1840: vol. 1, 186) in his reply to Pierre Bayle, so that the term 'Matérialiste' made its entrance in the French language. Moreover, by evoking 'les hypothèses d'Épicure et de Platon, des plus grands Matérialistes et des plus grands Idéalistes', the hypotheses of Epicurus and Plato, of the greatest materialists and idealists, Leibniz also invented one of the most resilient dichotomies of modern philosophy, and at the same time he projected it back in time. By the irony of history, Leibniz was to undergo the same projective treatment in the hands of Georg Wilhelm Friedrich Hegel, who enlisted him in the idealist ranks, ${ }^{4}$ although Leibniz would not have defined himself as an idealist thinker. However, long before Hegel's enlistment, it was another Anglican cleric, namely, Samuel Clarke, who instead countered Leibniz that his supposed 'Notion of the World's being a great Machine, going on without the Interposition of God, as a Clock continues to go without the Assistance of a Clockmaker; is the notion of Materialism and Fate' (Clarke \& Leibniz 1717: 15). The French version of Clarke's letter introduced the term 'Materialisme', (14) materialism, into French language.

As to the English language, both terms 'materialism' and 'materialist' kept being used for a while as attributions only. In 1713 Phylonous, a character in a dialogue written by George Berkeley, asked 'whether Materialism disposes Men to believe the Creation of Things' (1713: 154). There is probably no need to specify that the Anglican Bishop Berkeley believed himself to be anything but a materialist. And in 1739, also David Hume conceded that we cannot refuse to condemn the materialists, who conjoin all thought with extension' (1896: 239). At least, Hume immediately added that there is 'equal reason for blaming their antagonists, who conjoin all thought with a simple and indivisible substance' (1896: 239).

\section{The Christian modern background}

The attitude towards religion was the actual issue at stake in the controversies upon materialism. After the wars of religion, European states kept close ties with acknowledged Christian churches. These ties ranged from the church's immediate subordination to the sovereign, as in England, to church control of political power, as in the Papal States. ${ }^{5}$ Whatever the modality of the link between church and state, we may safely say that Christian narratives cannot be severed from the process of construction of early modern nations. We may likewise safely argue that the eighteenthcentury claims of materialism were intertwining with emerging alternative modalities of relation between state and church institutions. A clear-cut example of this transformation was the series of decrees of expulsion of the Jesuit order from several European states in mideighteenth century. ${ }^{6}$ The expulsions of the Jesuits were followed by the acquisition of religious properties by the state. On the model of the French term 'sécularisation', English language registered these forced acquisitions as 'secularizations'.

The new term expanded the morphosemantic family of the word 'secular', which in the thirteenth century appeared in the English language to define both the nonmonastic, or secular clergy, and the worldly, or secular sphere. ${ }^{8}$ Whilst the word 'secularization' is clearly related to the worldly sphere, it also produces a shift from the theological horizon of the heaven versus earth dichotomy towards the political horizon of the religious versus nonreligious institutions. Yet we need to exert particular caution in constructing this shift, as since the late eighteenth-century narrative of laicisation ${ }^{9}$ of state and society, the so-called secularisation process became the foundational narrative of the whole modernist political spectrum, from the extreme left to the liberal right. With this caveat, I will now return to the earlier hazardous vindications of materialism. 


\section{Materialism as a claim}

For a long time after the wars of religion, declaring oneself a materialist was a dangerous move in areas under influence both of Reformed and Counter-Reformed churches. For example, still in the nineteenth century, and precisely in 1842, George Holyoake achieved the distinction of being the last person in the United Kingdom to be imprisoned on a charge of atheism..$^{10}$ However, the first materialist proclamation appeared in 1732, right after the death of its author, the Catholic priest Jean Meslier, who plainly declared in writing: 'all the products of nature are only made (...) according to the natural and blind laws of movement, which lies in the parts of matter of which they are composed'11 (1864: vol. 3, 217). Meslier not only claimed (albeit, until his death, privately) the identification of being with matter, ${ }^{12}$ but also his own atheism, ${ }^{13}$ together with his devastating hate for all priests and tyrants.

In his remarkably straightforward text, known as his 'Testament', Meslier approvingly quoted one of his acquaintances, who 'wished (...) that all the great men in the world and all the nobility could be hanged and strangled with the guts of the priests'14 (1864: vol. 1, 19). Meslier identified the source (...) of all evils (...) and all impostures' with the 'detestable politics of men', which included political and religious authorities. In the words of Meslier, "both the former and the latter not only made deftly use of force and violence, but they also deployed all kinds of cunning and tricks for seducing the people' (1864: vol. 1, 7).

In 1747, fifteen years after Meslier's death, Julien Offray de La Mettrie dared to state in his essay Homme Machine, Man a machine, that 'the entire universe contains only one single diversely modified substance'15 (1994: 76). After that, he had to flee to Prussia to get the protection of the local enlightened king Frederick II. La Mettrie contrasted materialism with spiritualism, as the two 'systems of philosophy concerning man's soul' (1994: 27). Moreover, he shared Spinoza's monism, but not the Spinozian correspondence of the order of things with the order of thought. ${ }^{16}$ As a good physician, La Mettrie rather claimed that thought was conditioned by the physiology of the human organism..$^{17}$ At any rate, La Mettrie regarded not only Spinoza as a materialist, but also René Descartes, though in disguise. ${ }^{18}$

As I am not dealing with the history of attributed materialism, I will move to the year 1749, when Denis Diderot published anonymously his Lettre sur les aveugles, à l'usage de ceux qui voyent, Letter on the blind for the use of those who see. Actually, in the Letter Diderot did not mention materialism, but he gave his definition of philosophical idealism: 'Those philosophers are termed idealists who, conscious only of their own existence and of the sensations that follow each other inside them, do not admit anything else. An extravagant system which (...) is the most difficult to combat, though the most absurd of all'19 (1749: 63-64). In the Letter, Diderot took further La Mettrie's argument of the effect of the sensations on thought, and he produced an extraordinary anthropological investigation on the construction of reality by blind people, as compared with the reality of those who can see. The astonishing suggestion of the inquiry was that neither contemporary morals, nor metaphysics, nor religion made sense in a world devoid of vision.

Not only Diderot and La Mettrie shared a sensualist approach: natural philosophers' attention to the senses was also encouraged by the 1671 publication in London of the novel Philosophus Autodidactus, The self-taught philosopher, which was originally written in Arabic by the twelfth-century theorist and physician Ibn Țufayl. ${ }^{20}$ When the Latin translation of the novel appeared in print, it gained a wide audience, and its syncretic Aristotelianism inspired John Locke and later on, Étienne Bonnot de Condillac and Jean-Jacques Rousseau, among others (see Russell 1994). However, in his letter on the blind Diderot went well beyond a sensualist justification of naturalism, as he depicted nothing less than a sensualist multiverse, in which different worlds took shape from different practices. $^{21}$

The focus on human practices was the most original feature of Diderot's most ambitious intellectual project, the renowned Encyclopédie, of which he was the founder, the main editor, and also one of the main contributors. ${ }^{22}$ Diderot was sure that his wide collection of human techniques from every field of human activity would have produced in time 'a revolution in the human mind' (1876: 140): unfortunately, his unprecedented attempt to break the millennial boundary between manual and intellectual practices is still far from being successful.

d'Holbach's (1770) Système de la Nature, the system of nature, was the first published atheist and materialist systematic treatise. It is worth mentioning the Borgesian fictional attribution of the book to another writer, JeanBaptiste de Mirabaud, who had died ten years earlier. ${ }^{23}$ Two years later, d'Holbach anonymously published Le Bon-Sens, the good sense, which was long ascribed to Meslier. For sure, we may detect a Foucauldian flavour ante litteram in d'Holbach's observation about the production of religious discourse: 'Ordinarily, religions are but formless rhapsodies, which are composed by new Doctors who make use of the materials of their predecessors, and who reserve to themselves the right to add (anything) or cut what does not fit their present view'24 (1772: 305).

In the nineteenth century, after the Restoration, the debate on materialism was resumed in Germany by the so-called Young Hegelians, who took their start from a materialist critique of religion. This critique was actually prefigured in the unpublished writings of the young Hegel himself, who claimed for his epoch the possibility 'to vindicate as property of men [sic], at least in theory, the treasures formerly squandered on heaven'25 (1907: 225). Ludwig Feuerbach construed such a vindication as a reversal: it was heaven that mirrored earth, and not vice versa. Accordingly, the essence of religion had to be sought in human nature. ${ }^{26}$ In 1843, Friedrich Engels, who was clearly not familiar with Meslier, complained that eighteenth-century materialisms 'did not attack the Christian contempt for and humiliation of Man, and merely posited Nature instead of the Christian God as the Absolute confronting Man' (Engels 2010a: 419). However, Engels also rightly added that in the eighteenth century 
'in politics no one dreamt of examining the premises of the state as such', and 'it did not occur to economics to question the validity of private property' (Engels 2010a: 419). Moreover, in Engels and Marx's new materialist approach, the critiques of state and private property were particular cases of the general critique of all the categories in the theories of society that were in denial of their own historical character.

Marx recalls that his attention to the material conditions of life harked back to the 1840s. ${ }^{27}$ In 1845 , he jotted down a synthesis of his views as a series of eleventh theses on Feuerbach's thought, which were published only posthumously in $1888 .{ }^{28}$ I would quote the remarkable beginning of the first thesis: 'The chief defect of all hitherto existing materialisms - that of Feuerbach included - is that the object, reality, sensuousness, is conceived only in the form of the object or contemplation; not as human sensuous activity, practice, not subjectively'29 (1941: 82). Arguably, Marx's emphasis on the subjective side of the object bears the influence of Hegel's understanding of 'das Wahre (...) als Subjekt', the True as Subject (1807: xx). This construction generated for the Young Hegelians Marx and Stirner the same epiphany: ideas appeared to both of them as human productions. Stirner too was critical of Feuerbach's formulations and, like Marx, he was not contented with the replacement of theology with the new humanistic approach. More than that, he suggested (1995: 55) that the substitution of the theological order with the secular one was just a 'change of masters' (Herrenwechsel, 1845: 84), which was signalled by a change of adjectives: that which before was called holy simply became human.

\section{Materialism and Radicalism Materialism and radicalisms}

From Stirner on, we need to follow two distinct theoretical lineages, because the path of materialism no longer immediately coincided with that of radical thinking: whilst Marx's recasting of materialism influenced socialist parties especially through Engels and then spread worldwide in the versions adopted by communist parties, Stirner's suspicions were endorsed by Nietzsche. Nietzsche conceived of his theoretical practice as an active intervention upon both past and present. In particular, his genealogical accounts made room for the practices hidden behind religious, moral and philosophical concepts. He construed these practices as the expression of the Wille zur Macht, ${ }^{30}$ which is generally rendered in English with the ambiguous phrase 'will to power'. Nevertheless, in an 1884 note, Nietzsche listed four items of metaphysics that had to be eliminated: matter, will, the thing in itself and purpose. ${ }^{31}$ Nietzsche came to use the term Wille, will, as a kind of non-psychological tendency, and he deployed Macht, power, less as a concept than as a hint to the unpredictable expansion of the ability to act. Hence, there were no longer personal and material entities behind the expressions of the Wille zur Macht, which would be better understood as the general tendency of action to expand. The expressions of this expansive trend, namely, deeds were the actual 'subjects' in Nietzsche's theoretical horizon, which took the shape of a vast network of practices.
Marx had died in 1883, a year before Nietzsche's note: there were a few dozen mourners at his funeral in London. ${ }^{32}$ Nine years after Marx's death, Engels (1892: Ix) described his and Marx's approach as 'historical materialism',33 a definition that Marx never used. Moreover, Engels' late attempt to produce an all-comprehensive materialist philosophy embracing both nature and society may appear to repeat that which both Marx and Engels himself had once scorned as the philosophical phrases of the materialists concerning matter' (2010: 105). Furthermore, the very notion of communism, which in 1845 Engels and Marx famously claimed as 'the real movement which abolishes the present state of things' ${ }^{34}$ (2010: 49), became a doctrine meant to investigate, in a Kantian manner, the conditions of possibility of political transformation. For example, in 1885 Engels defined communism as the "insight into the nature, the conditions, and the consequent general aims of the struggle waged by the proletariat' (Engels 2010b: 318).

It is again the irony of history that Marx's so-called historical materialism was embraced, together with his critique of political economy, in an economically underdeveloped country, namely, the Russian Empire. Since the 1860s, the Russian education reform had produced a new интеллигенция [intelligensiya], which was inspired by public intellectuals such as Vissarion Belinsky, Alexander Herzen and Nikolay Chernyshevsky. As Russian academic philosophers endorsed institutional politics, the new radical intellectuals rejected traditional philosophies and embraced positivism instead. Georgi Plekhanov, a former populist leader and an admirer of Herbert Spencer, elaborated his determinist version of historical materialism (see Plekhanov 1940), which was to influence Lenin and his generation of revolutionary leaders. At the beginning of the twentieth century, the reciprocal influence between Nietzsche's reception and the questioning of the cornerstones of European thought played an important role in European cultural life. Nevertheless, the catastrophe of the First World War channelled these powerful dynamics into the bottleneck of political conservatism. After the war, the success of Oswald Spengler's Decline of the West and the publication of Carl Schmitt's Political Theology showed that conservative intellectuals appropriated radical dismissals of modernities. ${ }^{35}$

At the other end of the political spectrum, Lenin regarded materialism as an essential theoretical weapon in the political struggle (see Lenin 1972). Unfortunately, he followed the ahistorical dichotomy of materialism versus idealism, as schematically construed by Engels in his 1888 essay Ludwig Feuerbach and the End of Classical German Philosophy. What is much worse, later versions of soviet materialism drifted towards tautology. Here is a particularly authoritative example, as it comes from the pen of Stalin: 'Marx's philosophical materialism holds that the world is by its very nature material' (1940: 15). In the meantime, the appropriation of Nietzsche's thought by conservative thinkers and even by the Nazis was vehemently denounced by authors such as Thomas Mann and Georges Bataille. ${ }^{36}$ However, only in the 1960s the work of Nietzsche began to be recovered as a radical 
rethinking of the European cultural legacy. Theorists such as Foucault, Deleuze and Derrida endeavoured to apply Nietzsche's formidable theoretical tools.

\section{Old and new radical thinking}

We may mention as the effect of the reinvestment, so to speak, of Nietzschean theoretical capital Deleuze's 1966 journal article Renverser le platonisme, Reversing Platonism, which resonated with Nietzsche's reversal of the history of European philosophy. Deleuze sought in the very Platonic text the tools for undermining the priority of Platonic ideas over their copies: in their Latin version of simulacra, Deleuzean bad copies were no longer subordinated to their Platonic models, but they referred to each other in an infinite chain of reference, whose differing and deferring drifts were soon to be defined as 'différance' by Derrida in his 1967 text De la grammatologie. Such an unlimited referential activity radically undermined the theoretical priority of identity, regardless of its material or immaterial instantiations.

In 1966, Derrida had already hinted to a Nietzschean - and somewhat Heideggerian too - grand narrative of European philosophy, which he described as 'a series of substitutions of center for center' (1978: 353). In other words, Derrida pointed out a veritable apparatus of replacement at work during the history of metaphysical thought. From this perspective, we may see that inasmuch as materialist thinkers claimed a constitution of reality alternative to that of Christian theology, they accepted the common metaphysical or, in modern jargon, ontological ${ }^{37}$ terrain, and they re-enacted its apparatus of replacement by substituting a metaphysical centre, god, with another metaphysical centre, nature. This substitution should not be understood as a concluded action, because the hegemonic power of a theoretical framework has to be continuously reconfirmed by its successful efforts to repeat itself. This is why also our contemporary evocations of materialism, inasmuch as they reconstruct the metaphysical ground, risk to renew the change of masters denounced by Stirner.

Actually, radical materialists such as Meslier, La Mettrie, Diderot and Marx already strove to steer away from the trap of metaphysics by keeping as a reference ethics (Meslier), epistemology (La Mettrie and Diderot), and politics (Marx). Nonetheless, these authors' deserving attempts were jeopardised by their inability to transcend the horizon of modern naturalistic metaphysics. In Marx's subtler materialist version, modern naturalism was modulated as the temporary historical and social objectivity of the categories of the supposed current mode of production. On the contrary, Stirner challenged the very boundaries of the modern naturalistic horizon. In particular, as if objecting in advance to Marx's notion of socio-historical objectivity, he declared:

You believe that you have done the utmost when you boldly assert that, because every time has its own truth, there is no 'absolute truth.' Why, with this you nevertheless still leave to each time its truth, and thus you quite genuinely create an 'absolute truth,' a truth that no time lacks, because every time, however its truth may be, still has a 'truth' (1995: 313).

Nietzsche built upon Stirner's rejection of truth a series of positive attempts at partially ordering reality, which he understood as being chaotic, that is, undetermined. ${ }^{38}$ These attempts also took the shape of a genealogical ordering of the past. Later on, Foucault appropriated Nietzsche's genealogical practice as a powerful way of rethinking both the past and its present outcomes. According to Foucault, a genealogical approach 'disturbs what was previously considered immobile; it fragments what was thought unified; it shows the heterogeneity of what was imagined consistent with itself' (1977: 147).

More important, this recovery of Nietzschean theoretical tools was not meant to construct just a more fluid, flexible and adaptable representation of how things stand. Deleuze remarked in a 1972 conversation with Foucault:

A theorising intellectual, for us, is no longer a subject, a representing or representative consciousness. Those who act and struggle are no longer represented, either by a group or a union that appropriates the right to stand as their conscience. Who speaks and acts? It is always a multiplicity, even within the person who speaks and acts (Deleuze \& Foucault 1977: 206).

According to Deleuze, representation no longer worked, in both its political and epistemic senses. This was because, in the words of Foucault, 'theory does not express, translate, or serve to apply practice: it is practice' (Deleuze \& Foucault 1977: 208). Deleuze then specified:

A theory is exactly like a box of tools. It has nothing to do with the signifier. It must be useful. It must function. And not for itself. If no one uses it, beginning with the theoretician (who then ceases to be a theoretician), then the theory is worthless or the moment is inappropriate. We don't revise a theory, but construct new ones; we have no choice but to make others (Deleuze \& Foucault 1977: 208).

These words echoed Nietzsche's opening of the Genealogy of Morals, in which he considered the work of another theorist: 'I referred to passages from this book (...) not in order to refute them - what business is it of mine to refute! - but, as befits a positive mind, to replace the improbable with the more probable and in some circumstances to replace one error with another' (2006: 6). This sarcastic substitution of a simulacrum of truth with another one was not meant to undervalue the huge theoretical effort behind Nietzsche's genealogical endeavour, which, in the words of Foucault, 'demands relentless erudition' (1977: 140). On the contrary, Nietzsche's refusal to appeal to truth was a strategic move that undermined at once Platonism, its various recastings, and the modern critical gesture, which always barters a new and better truth for the old one. There is no longer need to perpetuate this chain of substitutions of truths if we follow the example of the Foucauldian genealogist, who 'takes care of listening 
to history, rather than placing faith in metaphysics' (1971: 148). In this case, we learn that 'behind things there is something completely different: not their essential and timeless secret, but the secret that they have no essence, or that their essence was construed bit by bit with extraneous materials' (1971: 148). Materialism is no exception.

\section{Towards Novel Theoretical and Political Practices}

I would like to evoke again the Foucauldian genealogist to emphasise that her work is not just an exercise in erudition, but it is a contribution to the production of practices in the present, by constructing the path that links the present to the past. As in good historical reconstructions, this path is not linear, but is fragmented by interruptions, changes of direction, bifurcations and new beginnings. However, unlike even a good historian, a genealogist acknowledges historicist reconstructions as differentiating projections onto the past. This recognition is surely an improvement on the epistemic horizon of modern historiography: but yet more important is the genealogist's capacity to transcend this horizon because she is not afraid of trespassing the cognitive threshold and declaring her investment in the past. ${ }^{39}$

For Nietzsche, the stake was the overcoming of the human. Foucault produced his genealogical inquiries as tools for desubjugation from authoritarian constructions of subjectivities, and for the construction of alternative non-authoritarian subjectivities. My investment in the past is determined by a broadly intended political perspective, which cherishes the most participation not only to the use of resources but also to their construction. From my perspective, the notion of materialism should then be either restated or rejected according to its pragmatic contribution to participatory processes. This would not imply, as Plato already dreaded, the populist surrendering to the base relativism of the will of the majority. Of course, the threat of mob rule was instrumental in justifying the Platonic absolute severance of objective knowledge from unstable opinion, and in modern times it backed the split of political and scientific representation: ${ }^{40}$ yet this split can and should be rethought. As materialism emerged in the wake of scientific representation, this reconsideration will affect its contemporary role and relevance.

A major attempt at reconsidering the modern divide between science and politics is Latour's proposal of a 'Parliament of Things' (1993: 142). This proposal may be also understood as a partial - albeit twisted - answer to Ivan Illich's request for 'procedures to ensure that controls over the tools of society are established and governed by political process rather than by decisions by experts' (1973: 12). Humans and nonhumans would be seated side by side in Latour's metaphorical deliberative organ, with which he redesigns in a single stroke knowledge and politics. The enlarged parliament would reconcile scientific and political representation, which were split apart since the seventeenth-century controversy between Hobbes and Boyle. Latour explains: 'The mediators have the whole space to themselves. (...) Natures are present, but with their representatives, scientists who speak in their name. Societies are present, but with the objects that have been serving as their ballast from time immemorial' (1993: 144). Latour contends that his new politicoscientific constitution would only require the ratification of what scientists have always done: they have always spoken in the name of objects.

Of course, objections may be raised against the traditional modern position of the scientists in regard to their objects: the Baconian understanding of scientific apparatuses as contrivances to force nature to speak $^{41}$ is nowadays met not only with ethical criticism, but also with the powerful pragmatic critique of ecological disasters. The 'revenge of Gaia' urges us to renegotiate the scientists' mode of representing their objects: this representation needs to be modulated and, to a certain extent, partaken and reciprocated. In turn, a modulated and partially partaken and reciprocated representation would possibly not incur Deleuze's drastic rejection of political mediation, which he stigmatises as the 'indignity of speaking for others' (Deleuze \& Foucault 1977: 209). With this proviso, I would add that historians, and especially genealogists, may contribute to Latour's parliamentary deliberations with another crucial mediation. This would require nothing else than ratifying what historians have always done: in European culture, historians are in charge of communicating with the dead. More precisely, historians do not speak to the dead, but rather they make the dead speak. This is not just a ventriloquist's trick, because historians do engage with the deeds of the dead through things.

An immense and expanding hybrid network links the dead, the things, their living orderers and variously integrating, overlapping and even conflicting ordering techniques. The network includes a bewildering amount and variety of internal connections that also perform as cross checks. The vastness and the complexity of this network dwarf and ridicule the debates on historical objectivity, be it material or immaterial. Even regardless of its metaphysical implications, the simplistic notion of historical objectivity is but a fig leaf, which covers the obscene reduction of the work of the historian to the assembling of a jigsaw puzzle. Just like scientists, historians already operate according to evolving protocols of relations with things. All these protocols always appear to be at risk to be channelled through the double bottleneck of the scientific method (in the singular) and the historical method (in the singular), respectively. However, not only Feyerabend convincingly showed the irreducible plurality of scientific approaches (see Feyerabend 1975), but the variety and vivacity of contemporary historiographic methodological debates also witness an analogous historiographic pluralism.

In my enlarged version of the Latourian parliament, the two multiplicities of scientific and historiographic protocols would be necessary, albeit not sufficient, conditions of the reciprocal engagement of humans and nonhumans. At the risk of awkwardness, here the nouns 'humans' and 'nonhumans' may be better replaced by the verbs 'humaning' and 'nonhumaning', on the model of the verbs 'subjectivating' and 'objectivating'. This 
replacement may help to underline the historicity of the split between humans and nonhumans, which also iterates the traditional European preposterous relation of the doer with the deed. As Nietzsche famously claimed, the doer did not precede the deed, but she was instead 'invented as an afterthought'. ${ }^{42}$

Unfortunately, this invention is well entrenched in European languages, where it took the shape of the standard grammatical structure subject-verb-predicate. Obviously, one cannot radically modify the structure of the language that one is using: nonetheless, it is possible to underscore the centrality of practices by emphasising verbs over subjects and predicates, and especially abstract nouns. This emphasis would help to undermine essentialism by turning its very linguistic weapons against it. In order to better defuse the power of the specific weapon branded by materialist essentialism, namely, matter, I will briefly recall its process of construction: this recollection will require a step back in time.

\section{Matter: A Genealogical Sketch}

The etymological root of the term 'materialism' is the Latin word materia, which originally denoted the trunk of a tree regarded as the mother - mater in Latin - of its offshoots. The sense of materia then developed under the influence of the Greek word Uै $\lambda \eta[h y l \bar{e}]$, of which it was the accepted equivalent in philosophical use. The parallel semantic paths of the Latin materia and the Greek hyle are part of the process that produced the European theoretical vocabulary by turning the Homeric language of actions into a constellation of abstract nouns (see Havelock 1986). In the course of this process, the sense of the Greek term hyle shifted from that of a natural habitat, namely, the fores ${ }^{43}$ to the specific (burning) material which we derive from it, that is, wood, ${ }^{44}$ and then to 'material' in general, probably by analogy with human productive activities. ${ }^{45}$ It was Aristotle who made hyle assume the function of the absolutely undetermined stuff ${ }^{46}$ to be shaped by the

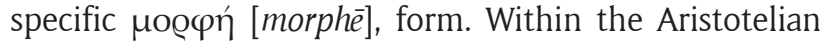
hylomorphic framework, the abstract indetermination of hyle was the necessary counterpart of the determining potential of the form, which guided the becoming of matter without being altered by it.

Whilst hylomorphic assumptions, including the indetermination of matter, still survive in our theoretical language, in the seventeenth century hylomorphism was dismissed as a physical explanation. Natural philosophers such as Galileo Galilei, Descartes and Hobbes distanced themselves from Aristotelian physics by no longer appealing to matter, but rather to its primary qualities, which they conceived of as being measurable, and thus objective. The measurement of these qualities made abstraction of the determination of matter, which enjoyed global properties in the shape of principles of conservation. These principles were the actual basis of both modern physics and chemistry. However, from time to time conservation principles included factors such as light and heat, ${ }^{47}$ which nowadays we do not deem material. The reciprocal convertibility of material and non-material factors became explicit when Albert Einstein, after dealing with the intricacies of measurement practices, ${ }^{48}$ had to include an overtly non-material parameter, namely, energy in the global equation of conservation, which is known as the relativity principle: $e=m c^{2}{ }^{49}$ The exploration of the subatomic dimension then added a further challenge to the status of physical objects: subatomic entities deeply puzzled physicists by behaving alternatively as either material bodies or waves.

The physicist and theorist Bohr was ready to accept the huge challenge that the new subatomic physics posed not only to modern physics, but to European thought at large..$^{50}$ As modern physics since its inception was supposed to represent the physical world, not only the knowledge of reality, but also its very constitution was at stake: in modern ${ }^{51}$ philosophical jargon, the challenge was not only epistemological, but also ontological. According to Bohr, the ontological instability of subatomic particles could be understood by acknowledging that nothing exists until it is measured. This bold statement seems to repeat Berkeley's dictum 'Esse is Percipi', to be is to be perceived (1710: 44). Berkeley grounded his challenge to the traditional metaphysical understanding of the continuity of the world on his faith in the ceaseless work of the Christian god: in other words, according to Berkeley, the very permanence of objects was the result of the iterated intervention of god..$^{52}$ On the contrary, within Bohr's godless world this continuity had to rely on the iteration of human practices. ${ }^{53}$

\section{A New Materialism? Barad's Agential Realism}

Bohr's remarkable endeavour of overcoming the divide between subject and object was recently resumed by Barad:

Instead of there being a separation of subject and object, there is an entanglement of subject and object, which is called the 'phenomenon'. Objectivity, instead of being about offering an undistorted mirror image of the world, is about accountability to marks on bodies, and responsibility to the entanglements of which we are a part (Dolphijn \& van der Tuin 2012: 52). ${ }^{54}$

Barad's notion of agential cut as 'a "holding together" of the disparate itself' (2012: 46) translates - with a Derridean overtone - Bohr's understanding of subatomic phenomena as entanglements: moreover, her contention that such a cut produces materialisations implies at the same time an assumption of responsibility for this production. Furthermore, with her general notion of 'phenomenon' Barad carries beyond the subatomic world ${ }^{55}$ Bohr's challenge to the separate identity of subjects and objects: 'A phenomenon is a specific intra-action of an "object" and the "measuring agencies"; the object and the measuring agencies emerge from, rather than precede, the intra-action that produces them' (2007: 128). Barad's notion of intra-action ushers in a relational ontology, in which entities in general do not precede their supposed interactions. She even translates the concept of matter into processes of 'spacetimemattering' (2007: 179). ${ }^{56}$ 
Here the verb 'spacetimemattering', as compared to the nouns 'space', 'time' and 'matter', emphasises the priority of practices over their conceptual products. Moreover, spacetimemattering practices extend to both past and future, which according to Barad are iteratively reconfigured and enfolded through the world's ongoing intra-activity' (Dolphijn \& van der Tuin 2012: 66). This implies that "in an important sense, the "past" is open to change. It can be redeemed, productively reconfigured in an iterative unfolding of spacetimematter' (Dolphijn \& van der Tuin 2012: 67). Yet Barad warns that 'changing the past is never without costs, or responsibility' (Dolphijn \& van der Tuin 2012: 67), and she quotes Astrid Schrader for arguing that memory is not a matter of the past, but it recreates the past each time it is invoked (see Schrader 2010).

Barad places her extraordinary reconnection of 'ethicoonto-epistemological'57 matters under the label of 'agential realism' (2007: 26). Moreover, she seems to be not uncomfortable with a broadly intended definition of materialism. In this case, Barad's proposals take materialism a long way from its traditional stances, and beyond the theoretical objections to its traditional formulations. Why then not embrace Barad's notion of agential realism, and why resist its appropriation under the broader umbrella of new materialism? Let us consider her statement: 'the very nature of materiality itself is an entanglement' (Dolphijn \& van der Tuin 2012: 69). For Barad '[t]o be entangled is not simply to be intertwined with another, as in the joining of separate entities, but to lack an independent, self-contained existence' (2007: IX). This entanglement is thus the answer to the question about the very nature of materiality.

That which is problematic here is not entanglement as a solution, but rather the iteration of the problem that entanglement is meant to solve: 'How to construct a better realism, a better materialism, a better materiality?' These are the questions that Barad appears to share in some degree with old and new materialisms: and despite her answer being arguably the most articulate and convincing to date, one still wonders about the relevance of the questions. I would for a moment take this relevance for granted: in this case, we may notice that Barad's approach overcomes the chief defect of all hitherto existing materialisms - that of Marx included: the preposterous position of reality and matter. Materialisms put the cart before the horse, as they treated the commonality of the world as a given, rather than a possibility to be construed. ${ }^{58}$ Barad's relational ontology obviates this defect, at the price of a radical transformation of the semantic constellation of realism, materialism and materiality.

\section{Otherwise Than Materialism}

\section{Objectivity: an embarrassing partaking}

I recalled how the resemanticisation of the notion of materialism, as practiced by Diderot and Marx among others, renewed materialism's vitality. Nevertheless, one may wonder about the significance of repeating this operation in a substantially different historical context. I previously showed how the modern claims of materialism emerged as the daring and defiant reversal of a term of reprobation, namely, materialism itself, into the proud assertion of an intellectual and political alternative. Materialists risked their lives for clashing head-on with modern Christian fideisms inasmuch as the latter supported authoritarian regimes and social structures. ${ }^{59}$ If we compare Diderot's and Marx's historical conditions with our neoliberal dark age, we still find widespread religious fideism. Nevertheless, at least in Europe, faith is no longer the main pillar of thrones nor of parliaments: it not only generally embraces technological advancement, but it also often kneels before the alleged inevitability of the course of the economy and its laws, which were construed as a merely parasitic simulacra of the laws of physics.

If we had to list the major ideological sources of legitimation for current European and Europeanized institutional policies, it would be difficult to challenge the priority of the double objectivity of economic laws and methodological individualism. Whilst these two beliefs do not exclude - especially in the United States - the supplement of religious faith, they rely on the authority of scientific statements. Modern sciences built this authority on two related claims: the objectivity of the natural world, and the ability of scientists to objectively represent nature. These claims are still exploited (more or less surreptitiously) by neoliberals in their economic theories and in their simplistic anthropology.

Materialism historically spearheaded both claims, though Marx cautioned about constructing knowledge as merely mirroring reality. On the contrary, Barad follows Bohr's contention that 'quantum theory exposes an essential failure of representationalism' (2007: 124). Moreover, she refashions the objectivity of natural facts as the reality of phenomena. By doing so, Barad rescues her notion of materiality from an embarrassing partaking of naturalist metaphysics with the hegemonic neoliberal discourse. ${ }^{60}$ Yet the point is whether the objectivism of economic rationalism and methodological individualism would be better confronted from the inside, as it were, by emptying the notions of reality and materiality of their absolute out-there-ness, ${ }^{61}$ or from the outside, by appealing to notions that do not share the neoliberal modern lineage. This choice is not a matter of truth, but a pragmatic bet on either the potential of a radically new understanding of matter to take hold, or the ability of another theoretical framework to spread.

\section{Another wager: from matter to practices}

Unfortunately, Barad's brilliant resemanticisation of reality and matter may also not be able to overturn the commonsensical understanding of both words. Paradoxically, it is the very radicality of Barad's resemanticisation that risks confining it to a niche of marginal theorists. Of course, the production of theoretical novelty is always a risky business. But even if both the recasting of materialism and its abandonment carried the same risk of marginalisation, I would rather go for a Pascalian move (albeit parodic) and raise my wager. In other words, the potential loss being the same in both cases, I would maximise the potential gain. Instead of betting on the theoretical defusing of one metaphysical object by emptying it out of its 'external' objectivity, I 
would choose the strategy of stripping any metaphysical object of its alleged objectivity, by composing it with its process of production.

In this paper, I exemplified such a composition with my genealogical construction of the processes of production of the object 'materialism', and with my sketchy genealogy of the object 'matter'. Both genealogical paths can incorporate Barad's construction as a (provisional) last step, without having to pay allegiance to her ontological commitments. Ontology itself, being a highly polysemous theoretical object, should be rather composed with its various processes of production. ${ }^{62}$ Of course, this composition has nothing to do with the prioritisation of language. On the contrary, when language constructions are composed with the practices of their production, they are acknowledged as objects, that is, things, or, more precisely, products. If any priority is affirmed here, it is that of practices. I did similarly operate elsewhere (and with surprising effects) on several other theoretical objects, including economy, freedom, individual, and time (see, e.g., Baldissone 2017, 2019): quite obviously, there is no limit to such compositions. This alone may tilt the previous comparison in favour of the abandonment of the label of materialism. Moreover, the appeal to practices of production would help overcoming the solipsistic underpinning of idealist and materialist epistemologies alike.

Diderot already confronted solipsist idealism with his apologue of the deranged harpsichord, which is in denial of its shared condition of produced object (see Diderot 2015: 95). Yet, not only the absolute subjectivity of the idealist construction of reality but also the absolute objectivity of the (old) materialist world renders the plurality of knowing subjects superfluous. It is not difficult to recognise in both views the (generally unacknowledged) theological legacy of the Christian god, who is alternatively either the idealist creator or the materialist omniscient observer. ${ }^{63}$ Even in Marx, the plurality of the knowing subjects is resolved into the oneness of the collective and its production of a unified singular knowledge: 'I presuppose, of course, a reader who is willing to learn something new and therefore to think for himself'64 (1872: 4). Barad's claim of the reality of phenomena rightly rejects objectivity as premised on an absolute notion of externality between observer and observed. Yet, whilst the relocation of reality allows her to meet the universe halfway - as brilliantly claims the title of one of her books - the very appeal to reality (in the singular $\left.{ }^{65}\right)$ would not help her multiversal encounters. If Haraway (2003: 1) is right in reminding us not only of a plurality of cultures, but also of a plurality of natures, one reality will not be enough for the multiplicity of ' $[\mathrm{e}]$ mergent [n]aturecultures', and we would better think in multiversal rather than universal terms.

I would exemplify this necessity by emphasising that reality as construed by European sciences relies on the possibility of repeating laboratory occurrences. In other words, it is long accepted that phenomena can be iterated ceteris paribus, that is, all other things being equal. For example, European science's engineered crops grow spectacularly well, ceteris paribus, also on other soils. However, the very ceteris paribus condition radically erases all differences, and this erasure has a cost. ${ }^{66}$ The appeal to reality (in the singular) does not help acknowledging this cost, which has been often paid in form of human assimilation and genocide. On the contrary, the appeal to practices may help assessing the cost of production of realities (in the plural). Of course, this assessment is not to be conducted only by a body of experts (however qualified), but it rather requires a wider negotiation, of which the Latourian parliament - plus my suggested enhancement - may be considered as an embryo, so to speak.

\section{Recomposing theoretical objects with their processes of production as a pluralist political tool}

It may be objected that the notion of parliament also has a history, which includes parliamentary practices. And it may also be observed that, similarly to materialism, parliamentarism has known better days, especially in Europe. Why then put such an emphasis on a somewhat discredited instrument, and why even use it as a model? Again, if the assessment has to be contextual, my answer is: pluralism. If we apply the pluralist model of parliamentary decision-making to knowledge, commonalities will be recognised as the result of pluralistic agreements ${ }^{67}$ rather than preconditions to the negotiation. Neither economic rationalism, nor methodological individualism can afford the costs of pluralism. On the one hand, economic neoliberal orthodoxy relies on the suppression of heterodox economic theories, which often have no space even in academic economic departments. On the other hand, methodological individualism simply erases supra- and sub-individual components and compositions.

However, the aim is not to simply disprove neoliberal tenets, but to render neoliberal practices impractical. This task cannot be achieved through mere resistance to neoliberal policies, but rather as the wager of alternative practices and policies that make neoliberal behaviour less and less enticing and feasible. To this end, the productive role of theories, or better, theoretical practices, can be hardly overestimated. And whilst the acknowledgement that interaction precedes the emergence of entities is a step towards meeting the (European) universe halfway, the recomposition of theoretical objects with their processes of production at once provincialises the European world and opens towards multiversal negotiations.

If radical thinkers raise the stake, they will set again for themselves a worthy alternative, namely, that one between marginalisation and hegemony. This was also the historical wager of modern materialism, although the metaphysical framework in which it emerged made materialist theorists conceive of their struggle for cultural hegemony as a confrontation between totalising truths. Paradoxically, by abandoning the banner of materialism, radical thinkers could renew materialist hegemonic strategies. That's why it is not without nostalgia that I invite you to let go our long-cherished matter. Paraphrasing Adorno, radical thinking feels solidarity with materialism at the moment of its fall. ${ }^{68}$ 


\section{Notes}

1 '[D] efinirbar ist nur Das, was keine Geschichte hat.' All translations are mine, unless otherwise specified. Retrieved on the Website of Nietzsche's Digital Critical Edition at: http://www.nietzschesource.org/\#eKGWB/ GM-II-13.

${ }^{2}$ I explained elsewhere why I would prefer using the neologisms 'geneurgy' and 'geneurgical', which underline also etymologically the productive intervention of the genealogist as geneurgist: in this paper I will keep using the terms 'genealogy' and 'genealogical' only for the sake of clarity.

${ }^{3}$ The noun 'Hylobares' is a pun in Greek on the weighing down (barein) effect of matter (hylē) as opposed to spirit.

4 'Leibnitz's philosophy is an idealism of the intellectuality of the universe.' In Hegel 1896: 330.

${ }^{5}$ Still in both the United Kingdom and the Vatican City State (which is the heir of the Papal States) the head of state exerts her authority also over the local church (though since 1559 the official title of the English sovereign is 'Supreme Governor of the Church of England').

${ }^{6}$ In France, the 1762-1764 expulsion was the result of the pressure exerted by an unprecedented and wide alliance, which ranged from the Jansenists to the Philosophes, and which even included the royal mistress, Madame de Pompadour.

${ }^{7}$ Whilst the expropriation of church property is a sixteenth-century English phenomenon, the English word 'secularization' is first attested in John Kersey's 1706 edition of Edward Phillips' English dictionary, and it is defined as 'the Act of Secularizing'.

8 See OED, 'secular, adj. and n.'

9 The word 'laicization', from the French term laicisation, is first documented in English in the 1880s. See OED, 'laicization, n'.

${ }^{10}$ Holyoake enjoyed the hospitality of the Gloucester gaol for six months.

11 'Tous les ouvrages de la nature ne sont faits [...] que par le seules loix naturelles et aveugles du mouvement, qui se trouve dans les parties de la matière, dont ils sont composés.'

12 'L'Être en général et sans restriction, ou l'être infini, n'est autre chose que la matière,' Being in general and without restrictions, or the infinite being, is nothing else than matter' (1864: vol. 3, 172).

13 '[L]'Athéisme n'est pas une ópinion si étrange, ni si monstrueuse et si dénaturée que nos superstitieux Deicoles le font entendre,' atheism is not such a strange, monstruous and innatural opinion as our superstitious God-worshippers would lead us to believe (1864: vol. 2, 297).

14 'Il souhaitoit (...) que tous les grands de la terre et que tous les nobles fussent pendus et étranglés avec les boïaux des prêtres.' It is not surprising that Voltaire promoted only a reduced and expurgated version of Meslier's text, which he also disparagingly defined as being 'écrit du style d'un cheval de carrosse', written in the style of a carriage horse (that is, brutal), in his 1 May 1763 letter to Helvétius. In Voltaire 1832: 20.
15 '[I]l n'y a dans tout l'Univers qu'une seule substance diversement modifiée.' In Anonymous 1748: 107.

${ }^{16}$ The famous Proposition 7 of the second book of Spinoza's Ethica reads: 'Ordo, and connexio idearum idem est, ac ordo, \& connexio rerum', the order and connection of ideas is the same as the order and connection of things. In Spinoza 1677: 45.

17 There is a kind of ferocious and sinister irony in the fact that La Mettrie died from accidental food poisoning.

${ }^{18}$ La Mettrie describes the Cartesian distinction between the thinking and the extended substance as 'un tour d'addresse,' a trick of skill to deceive the theologians (1748: 95).

19 'On appelle Idéalistes, ces philosophes, qui n'ayant conscience que de leur existence \& des sensations qui se succedent au-dedans d'eux-mêmes, n'admettent pas autre chose. Systême extravagant, qui (...) est le plus difficile à combattre, quoique le plus absurde de tous'.

${ }^{20}$ Edward Pococke published in 1671 his Latin translation - arguably largely executed by his homonymous father, a renowned Arabist - of the philosophical fable حي بن يقظان [Hayy ibn Yaqūān], by Ibn Ṭufayl, who was known in Christian Europe as Abubacer.

${ }^{21}$ Diderot's daring text granted him an imprisonment of more than three months in the tower of the fortress of Vincennes: he was freed thanks to a plea to the police by Le Breton and his other publishers, who were worried about the interruption of the project of the 'Dictionnaire universel des sciences, arts et métiers,' universal dictionary of the sciences, arts, and crafts, that was to become the Encyclopédie, Encyclopaedia. See manuscrit 11761, f. 8, Archives de la Bastille, Bibliothèque de l'Arsenal, retrieved at: https://gallica. bnf.fr/ark:/12148/btv1b10070899m/f14.item.

${ }^{22}$ The Encyclopédie, ou Dictionnaire Raisonné des Sciences, des Arts et des Métiers, Encyclopaedia or a systematic dictionary of the sciences, arts and crafts, was published between 1751 and 1772, with later additions, under the supervision of Diderot and (until 1759) Jean Le Rond d'Alembert.

${ }^{23}$ The alleged author Jean-Baptiste de Mirabaud, Secretaire Perpetuel de l'Académie Française, Perpetual Secretary of The French Academy, died on the 24 June of 1760 , at the age of 85 . The fictional attribution of the book was meant to escape censorship, but also to pay homage to a deceased freethinker and to embarrass the Académie. See d'Holbach 1770.

24 'Les religions ne sont pour l'ordinaire que des rapsodies informes combinées par de nouveaux Docteurs, qui pour les composer se sont servis des matériaux de leurs prédécesseurs, en se réservant le droit d'ajouter ou de retrancher ce qui ne convenoit point à leurs vûes présentes.'

25 ' $D]$ ie Schätze, die an den Himmel verschleudert worden sind, als Eigentum der Menschen, wenigstens in der Theorie, zu vindizieren'. This sentence appears in the 1795-1796 Hegelian essay Die Positivität der christlichen Religion, The Positivity of Christian Religion, which was only published in 1907 in the volume Hegels Theologischen Jugendschriften, Hegel's early theological writings. 
26 See Feuerbach 1841.

27 'Im Jahr 1842-1843, als Redakteur der "Rheinischen Zeitung", kam ich zuerst in die Verlegenheit über sogenannte materielle Interessen mitsprechen $\mathrm{zu}$ müssen'. In the year 1842-1843, as editor of the Rheinische Zeitung, I first found myself in the embarrassing position of having to discuss so-called material interests. In Marx 1859: IV.

${ }^{28}$ Marx's Theses on Feuerbach first appeared in print in 1888, as an appendix to Engels' book Ludwig Feuerbach and the End of Classical German Philosophy. See Engels 1888.

29 'Der Hauptmangel alles bisherigen Materialismus den Feuerbach'schen mit eingerechnet - ist, dass der Gegenstand, die Wirklichkeit, Sinnlichkeit, nur unter der Form des Objekts oder Anschauung gefasst wird; nicht aber als sinnliche Thätigkeit, Praxis, nicht subjektiv' (Engels 1888: 69).

30 The phrase Wille zur Macht first appears in a Nietzsche's note written in 1876: 'Furcht (negativ) und Wille zur Macht (positiv) erklären unsere starke Rücksicht auf die Meinungen der Menschen.' Fear (negative) and will to power (positive) explain our strong consideration for people's opinions. Retrieved at: http://www.nietzschesource.org/\#eKGWB/NF-1876, 23[63].

31 '[K]ein Stoff (Boscovich)

kein Wille

kein Ding an sich

kein Zweck'

No matter (Boscovich)/no will/no thing in itself/no purpose. Ruggiero Boscovich is an eighteenth-century Italo-Croatian thinker who devised a physics based on forces rather than matter. See also Ansell-Pearson 2000. Retrieved at: http://www.nietzschesource.org/? \#eKGWB/NF-1884,26[302].

${ }^{32}$ It is fair to recall that one year later several thousand people marched to the cemetery to commemorate Marx.

33 The phrase 'historical materialism' first appears within double brackets in Engels' introduction to the 1892 English edition of his book Socialism: Utopian and Scientific, which is an extract from his larger book Herrn Eugen Dühring's Umwälzung der Wissenschaft, best known as Anti-Dühring. In the introduction, Engels (vII) also recalls the unprecedented success of his extract: 'I am not aware that any other Socialist work, not even our "Communist Manifesto" of 1848, or Marx's "Capital", has been so often translated'.

${ }^{34}$ This rightly famous definition of communism as a process and not as an idea is the productive effect of Marx and Engels' confrontation with Stirner.

35 See Spengler 1918-1922 also Schmitt 1922. Schmitt was an avid and grateful reader of Stirner, but he reduced Stirner's theoretical gist to the acknowledgement that the 'I' is not an object of thought. See Schmitt 1950.

36 See for example, the second issue of the magazine Acéphale (January 1937).
37 Jacob Lorhard invented in 1606 the Latin term 'ontologia', that is, ontology as a synonym for metaphysics (1606: 1).

38 The Greek word Xóos [Khaos] first appeared in Hesiod's Theogony to name the personification of a primordial undetermined condition: Nietzsche underlined that "[d]ie Griechen lernten allmählich das Chaos zu organisiren', the Greeks learned how to organize Chaos, whose transliterations in modern European languages, including the English word 'chaos', only in the seventeenth century acquired the current sense of 'disorder'. Nietzsche not only restated that '[d]er Gesammt-Charakter der Welt ist dagegen in alle Ewigkeit Chaos', the general character of the world, however, is to all eternity chaos, but he had Zarathustra address at once audience and readers: 'ihr habt noch Chaos in euch', you have still chaos in you. The Nietzschean use of 'chaos' may be compared with that of the supposed Anaximandrian notion of

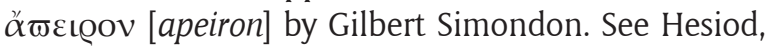
Theogony 116. Retrieved at:

http://www.nietzschesource.org/\#eKGWB/HL-10 http://www.nietzschesource.org/\#eKGWB/FW-109 http://www.nietzschesource.org/\#eKGWB/Za-IVorrede-5.

39 'Historians take unusual pains to erase the elements in their work which reveal their grounding in a particular time and place, their preferences in a controversy the unavoidable obstacles of their passion' (Foucault 1977: 156-157).

${ }^{40}$ Most modern theorists, in order to avoid the 'inhuman' mob, chose 'to rely on another inhuman resource, the objective object untouched by human hands' (Latour 1999: 13).

${ }^{41}$ In comparing matter with the Greek god Proteus, Bacon urges to restrain 'Materia,' matter by keeping it 'per Manicas (...), id est, per Extremitates,' by the sleeves, that is, by the extremities (Bacon 1617: 52.)

42 "[T]here is no "being" behind the deed, its effect and what becomes of it; the "doer" is invented as an afterthought - the doing is everything' (Nietzsche 2006: 26).

${ }^{43}$ Homer, Iliad 2.455; 3.151.

${ }^{44}$ Homer, Iliad 7.18; 7.20.

45 See OED, 'matter, n.1.'

${ }^{46}$ Aristotle, Physics 192a31-32.

${ }^{47}$ For example, in the 1780s Antoine Lavoisier applied the Newtonian principle of conservation of mass to chemical reactions in order to demonstrate a general law of conservation of matter. He included in the latter's definition also light and heat or caloric, which he considered material substances. Moreover, in 1837 Karl Friedrich Mohr enlisted motion together with light, chemical affinity, cohesion, electricity and magnetism in that which is considered as an earlier statement of the principle of conservation of energy.

${ }^{48}$ Einstein reached puzzling results in dealing with measurement as a practice (albeit from within thought experiments). I would venture as far as suggesting to construct measurement as a kind 
of Deleuzian-Guattarian agencement, that is, as a composition of measuring tools and measured objects: a spacetimemattering activity, in Barad's language.

${ }^{49}$ Although the relation $e=m c^{2}$ was implied by the 1905 formulation of relativity theory, it first appeared in this form in 1907 (see Einstein 1907).

${ }^{50}$ Barad (2007) rightly underlines that also the understanding of one of the fundamentals of the new physics, namely, Heisenberg's indetermination principle is substantially owed to Bohr.

51 The English word 'epistemology' first appears in printing in 1847 in an anonymous review of three books by Jean Paul Friedrich Richter: in a note, the reviewer explains that he translates as 'epistemology' the title of Johann Gottlieb Fichte's book Wissenschaftslehre. In Anonymous (1847). Jean Paul. The English Review, (2) March-June. London: Francis \& John Rivington, 276-313, 296, note 9. After Lorhard coins the Latin word 'ontologia', Gideon Harvey first uses the English term 'ontology' in 1663 (1663: 18).

52 "Tis therefore plain, that nothing can be more evident to any one that's capable of the least Reflexion, than the Existence of GOD, or a Spirit who is intimately present to our Minds, producing in them all that variety of Ideas or Sensations, which continually affect us' (Berkeley, 1710: 203-204).

${ }^{53}$ We may speculate on a Nietzschean influence on Bohr, who knew the work of Nietzsche through Georg Brandes. Bohr much admired Brandes, who was a friend of his father and had been in personal contact with Nietzsche. Brandes taught at the University of Copenhagen the first course ever on Nietzsche's philosophy, which he defined as 'aristocratic radicalism', much to the pleasure of Nietzsche himself.

${ }^{54}$ Barad's sense of 'accountability' remarkably transcends the cognitive boundary, as she is adamant on her stakes: 'My passion for my work is utterly and completely grounded, and hopefully always with its feet attached to the ground, in questions of justice and ethics' (Dolphijn \& van der Tuin 2012: 67).

55 'The epistemological and ontological issues are not circumscribed by the size of Planck's constant' (2007: 70).

56 '[C]hange is not a continuous mutation of what was or the unraveling of what will be, or any kind of continuous transformation in or through time, but the iterative differentiatings of spacetimemattering'.

57 Barad constructs the adjective 'ethico-ontoepistemological' (2012: 46) in order to underline the compenetration of these traditionally distinct theoretical fields.

58 In my language, there are no defective theories. Hence, putting the cart before the horse is not a theoretical fault, but rather a historically iterated practice with which Europeans imposed (and still impose) their image of the world as the common world.

${ }^{59}$ Already in 1938, the communist theorist and activist Anton Pannekoek (1948) retrospectively imputed to Lenin to dehistoricize this contextual ideological confrontation by turning it into the abstract antagonism between materialism and idealism.
${ }^{60}$ Foucault already put it bluntly (2012: 161): 'Power has become materialist'.

${ }^{61}$ The hyphenated term 'out-there-ness' was used to translate into English the Heideggerian term Vorhandenheit: on the contrary, I use it in the sense of (construed) objectivity as in Woolgar and Latour 1979: 182.

62 If I had to write a genealogy of ontology, following the approach of this essay I would begin in 1606: I would then go both forward and backward in time from there, in order to map also modern retrospective projections of the notion of ontology (see Baldissone 2021).

${ }^{63}$ In this sense, we may find two ancestors to idealism and materialism in the medieval juridico-theological alternative notions of divine law: lex imperativa, prescriptive law and lex indicativa, ostensive law.

64 'Ich unterstelle natürlich Leser, die etwas Neues lernen, also auch selbst denken wollen.' My italics. In Marx 1872: 4. In this quote from the preface to Capital, Marx presupposes that by thinking for oneself, one would reach his same conclusions. Marx concludes the preface with a telling misquotation from Dante: 'Segui il tuo corso, e lascia dir le genti!' Follow your own course, and let people talk (8). The original line in the Commedia reads 'Vien dietro a me, e lascia dir le genti,' follow me, and let people talk (Dante, Purgatorio 5.12).

${ }^{65}$ Barad (2007: 471) writes: 'as far as we know the world is not broken up into distinct regions each with different physical laws and realities.' Just to remain within the boundaries of the world as construed by European sciences, Barad's 'we' clearly does not include, for example, Nancy Cartwright, who contends (1999: 31) that "nature is governed in different domains by different systems of laws not necessarily related to each other in any systematic or uniform way; by a patchwork of laws'.

${ }^{66}$ An example of the erasure produced by mononaturalist assimilationism is the US-supported green revolution: in Punjab (among other places), the introduction of more efficient European science's engineered monocultures increased the production of targeted crops, but it led to cultural, social and political disruption.

67 The worryingly influential versions of DSM, which is the acronym of the Diagnostic and Statistical Manual of Mental Disorders produced by the American Psychiatric Association, are an example of the danger of agreements reached only by selected experts on matter of general relevance.

${ }^{68}$ At the very end of his Negative Dialectics, Theodor Adorno (1973: 408) claims thinking's solidarity with metaphysics at the moment of its fall.

${ }^{69}$ Matter, may the soil be light upon you. The Latin motto 'sit tibi terra levis' is a common inscription on ancient Roman tombstones.

\section{Competing Interests}

The author has no competing interests to declare. 


\section{References}

Adorno, T. W. (1973). Negative Dialectics. London: Routledge \& Kegan Paul.

Anonymous [La Mettrie]. (1748). L'Homme Machine. Leyden: Elie Luzac.

Ansell-Pearson, K. (2000). Nietzsche's Brave New World of Force. Pli, 9, 6-35.

Bacon, F. (1617). De Sapientia Veterum. London: John Bill.

Baldissone, R. (2017). Farewell to Freedom: A Western Genealogy of Liberty. London:University of Westminster Press. DOI: https://doi.org/10.16997/book15

Baldissone, R. (2019). Autós: Individuation in the European Text. London: Rowman \& Littlefield.

Baldissone, R. (2021). The Unbearable Monstrosity of Being: On the Narrative Provincialization of Ontologies. In C. Nirta \& A. Pavoni (Eds.), Monstrous Ontologies (pp. 193-218). Wilmington, DE: Vernon Press.

Barad, K. (2007). Meeting the Universe Halfway: Quantum Physics and the Entanglement of Matter and Meaning. Durham, NC: Duke University Press. DOI: https://doi. org/10.1215/9780822388128

Barad, K. (2012). Nature's Queer Performativity. Kvinder, Køn og forskning/Women, Gender and Research 1(2), 25-53. DOI: https://doi.org/10.7146/kkf.v0i12.28067

Berkeley, G. (1710). A Treatise Concerning the Principles of Human Knowledge. Dublin: James Pepyat.

Berkeley, G. (1713). Three Dialogues between Hylas \& Philonous. London: Henry Clements.

Boyle, R. (1674). Of the Excellency and Grounds of the Corpuscular or Mechanical Philosophy, anne'xd to The Excellency of Theology, Compar'd with Natural Philosophy. London: Henry Herringman.

Cartwright, N. (1999). The Dappled World. Cambridge: Cambridge University Press. DOI: https://doi. org/10.1017/CBO9781139167093

Chattopadhyaya, D. (1959). Lokāyata: A Study in Ancient Indian Materialism. New Delhi: People's Publishing House.

Clarke, S., \& Leibniz, G. W. (1717). A Collection of Papers, Which Passed Between the Late Learned Mr. Leibnitz, and $d r$. Clarke, In the Years 1715 and 1716. London: James Knapton.

Cudworth, R. (1678). The True Intellectual System of the Universe. London: Richard Royston.

d'Holbach, P. H. T. (1770). Sistême de la Nature ou des Loix du Monde Physique \& du Monde Moral. Londres.

d'Holbach, P. H. T. (1772). Le Bon-Sens ou Idées Naturelles Opposées aux Idées Surnaturelles. Londres.

Deleuze, G. (1966). Renverser le Platonisme (Les simulacres). Revue de Métaphysique et de Morale, 71(4), 426-438.

Deleuze, G., \& Foucault, M. (1977). Intellectuals and Power. In Foucault, M., Language, Counter-Memory, Practice (pp. 205-217). Trans. Bouchard, D. and Simon, S. Ithaca, NY: Cornell University Press.

Derrida, J. (1967). De la grammatologie. Paris: Éditions de Minuit.
Derrida, J. (1978). Structure, Sign and Play in the Discourse of the Human Sciences. In Derrida, J., Writing and Difference (pp. 351-370). Trans. Alan Bass. London: Routledge \& Kegan Paul.

Diderot, D. (1749). Lettre sur les aveugles, à l'usage de ceux qui voyent. Londres.

Diderot, D. (1876). Correspondance. In Assézat, J. and Tourneux, M. (Eds.), Euvres Complètes 19. Paris: Garnier.

Diderot, D. (2015). Entretien entre D'Alembert et Diderot. In Diderot, D., Selected Philosophical Writings (pp. 83-98). Cambridge: Cambridge University Press.

Dolphijn, R., \& van der Tuin, I. (2012). Interview with Karen Barad. In R. Dolphijn \& I. van der Tuin (Eds.), New Materialism: Interviews \& Cartographies (pp. 48-70). Ann Arbor, MI: Open Humanities Press. DOI: https:// doi.org/10.3998/ohp.11515701.0001.001

Einstein, A. (1907). Über die vom Relativitätsprinzip geforderte Trägheit der Energie. Annalen der Physik, 23, 371-384. DOI: https://doi.org/10.1002/ andp.19073280713

Engels, F. (1888). Ludwig Feuerbach und der Ausgang der Klassischen Deutschen Philosophie. Berlin: Dietz.

Engels, F. (1892). Socialism: Utopian and Scientific. Trans. Aveling, E. London: Swan, Sonnenschein \& Co.

Engels, F. (2010a). Outlines of a Critique of Political Economy. In Engels, F. \& Marx, K., Marx and Engels Collected Works, 3, 418-443. London: Lawrence and Wishart.

Engels, F. (2010b). On the History of the Communist League. In Engels, F. \& Marx, K., Marx and Engels Collected Works, 26, 312-330. London: Lawrence and Wishart.

Engels, F., \& Marx, K. (2010). The German Ideology. In Engels, F. \& Marx, K., Marx and Engels Collected Works 5. Trans. Dutt, C., Lough, W. and Magill, C. P. London: Lawrence and Wishart.

Feuerbach, L. (1841). Das Wesen des Christentums. Leipzig: Wigand.

Feyerabend, P. (1975). Against Method. London: New Left Books.

Foucault, M. (1971). Nietzsche, la généalogie, l'histoire. In S. Bachelard (Ed.), Hommage à Jean Hyppolite. Paris: P.U.F.

Foucault, M. (1977). Nietzsche, Genealogy, History. In Foucault, M., Language, Counter-Memory, Practice. Trans. Donald Bouchard \& Sherry Simon. Ithaca, NY: Cornell University Press.

Foucault, M. (2012). The Meshes of Power. In Crampton, J. and Elden, S. (Eds.) Space, Knowledge and Power: Foucault and Geography (pp. 153-162). Trans. Moore, G. London: Ashgate.

Haraway, D. (2003). The Companion Species Manifesto. Chicago, IL: Prickly Paradigm Press.

Harvey, G. (1663). Archelogia Philosophica Nova. London: Thomson.

Havelock, E. (1986). The Muse Learns to Write. New Haven, CT: Yale University Press.

Hegel, G. W. F. (1807). Phänomenologie des Geistes. Bamberg und Würzburg: Goebhardt. 
Hegel, G. W. F. (1896). Lectures on the History of Philosophy 3. Trans. Elizabeth Haldane \& Frances Simson. London: Kegan Paul, Trench, Trübner \& Co.

Hegel, G. W. F. (1907). Hegels Theologischen Jugendschriften. Tübingen: Mohr.

Hume, D. (1896). A Treatise of Human Nature. Oxford: Clarendon Press.

Illich, I. (1973). Tools for Conviviality. London: Calder \& Boyars.

La Mettrie, J. O. (1994). Man a Machine and Man a Plant. Trans. Watson, R. and Rybalka, M. Indianapolis, IN: Hackett Publishing Company.

Latour, B. (1993). We Have Never Been Modern. Trans. Porter, C. New York: Harvester Wheatsheaf.

Latour, B. (1999). Pandora's Hope: Essays on the Reality of Science Studies. Cambridge, MA: Harvard University Press.

Le Goff, J. (1984). The Birth of Purgatory. Trans. Goldhammer, A. Chicago, IL: University of Chicago Press.

Leibniz, G. W. (1840). Réplique aux Réflexions, Contenues Dans la Seconde Edition du Dictionnaire Critique de Mr. Bayle, Article Rorarius sur le Système de L'harmonie Préétablie. In J. E. Erdmann (Ed.), Leibnitii Opera Philosophica Quae Extant Latina Gallica Germanica Omnia 1 (pp. 183-191). Berlin: G. Eichler.

Lenin, V. I. (1972). Materialism and Empiriocriticism. In Lenin, V. I., Lenin Collected Works. Moscow: Progress Publishers.

Lorhard, J. (1606). Ogdoas Scholastica. St. Gallen: Georg Straub.

Marx, K. (1859). Zur Kritik der Politischen Oekonomie. Berlin: Duncker.

Marx, K. (1872). Das Kapital: Kritik der Politischen Oekonomie. Hamburg: Meissner.

Marx, K. (1941). Theses on Feuerbach. In Engels, F., Ludwig Feuerbach and the End of Classical German Philosophy (pp. 82-84). Trans. Dutt, P New York: International Publishers.

Meslier, J. (1864). Testament. Amsterdam: Meijer.

More, H. (1655). An antidote against Atheism, or, An Appeal to the Natural Faculties of the Mind of Man, whether there be not a God. London: Flesher.
More, H. (1668). Divine Dialogues, Containing Sundry Disquisitions and Instructions Concerning the Attributes of God and His Providence in the World. London: Flesher.

Nietzsche, F. (2006). On the Genealogy of Morality. Trans. Diethe, C. Cambridge: Cambridge University Press. DOI: https://doi.org/10.1017/CBO9780511812026

Pannekoek, A. (1948). Lenin as Philosopher: A Critical Examination of the Philosophical Basis of Leninism. New York: New Essays.

Phillips, E., \& Kersey, J. (rev.) (1706). The New World of Words; or, Universal English Dictionary (6th edition). London: Printed for J. Phillips, H. Rhodes, and J. Taylor.

Plekhanov, G. V. (1940). The Materialist Conception of History. London: Lawrence and Wishart.

Russell, G. A. (1994). The Impact of the Philosophus Autodidactus: Pocockes, John Locke, and the Society of Friends. In G. A. Russell (Ed.), The 'Arabick' Interest of the Natural Philosophers in Seventeenth-Century England (pp. 224-266). Leiden: Brill. DOI: https://doi. org/10.1163/9789004247062_013

Schmitt, C. (1922). Politischen Theologie. München: Duncker \& Humblot.

Schmitt, C. (1950). Ex Captivitate Salus. Köln: Greven.

Schrader, A. (2010). Responding to Pfiesteria piscicida(the Fish Killer): Phantomatic Ontologies, Indeterminacy and Responsibility in Toxic Microbiology. Social Studies of Science, 40(2), 275-306. DOI: https://doi. org/10.1177/0306312709344902

Spengler, 0.(1918-1922). Der Untergang des Abendlandes. Wien: Braumüller; Beck: München.

Spinoza, B. (1677). Opera Posthuma. Amsterdam: Rieuwertsz.

Stalin, J. (1940). Dialectical and Historical Materialism. New York: International Publishers.

Stirner, M. (1845). Der Einzige und sein Eigenthum. Leipzig: Wigand.

Stirner, M. (1995). The Ego and Its Own. Trans. Byington, S. Cambridge: Cambridge University Press. DOI: https:// doi.org/10.1017/CBO9780511815959

Voltaire. (1832). Oeuvres de Voltaire 61. Paris: Lefèvre.

Woolgar, S., \& Latour, B. (1979). Laboratory Life: The Social Construction of Scientific Facts. Beverly Hills, CA: Sage.

\footnotetext{
How to cite this article: Baldissone, R. (2021). Materialism: A Caring Obituary. Anthropocenes - Human, Inhuman, Posthuman, 2(1), 12. DOI: https://doi.org/10.16997/ahip.1056
}
Submitted: 17 April 2021
Accepted: 24 June 2021
Published: 21 December 2021

Copyright: ( $) 2021$ The Author(s). This is an open-access article distributed under the terms of the Creative Commons Attribution 4.0 International License (CC-BY 4.0), which permits unrestricted use, distribution, and reproduction in any medium, provided the original author and source are credited. See http://creativecommons.org/licenses/by/4.0/. 